\title{
On the phenomenon of female juvenile delinquency $^{*}$
}

\author{
JOANNA BRZEZIŃSKA \\ Departament of Substantive Criminal Law \\ Faculty of Law, Administration and Economics \\ University of Wroclaw, Poland
}

\section{Preliminary remarks}

In the course of the research on female delinquency ${ }^{1}$ carried out by penal studies representatives, it was revealed that the belief that in recent decades the level of aggression of female delinquents has increased is ever more popular. ${ }^{2}$ No less disturbing is the remark that violence is observed in the behaviour of very young girls, and the phenomenon of the exacerbation of their crime-inducing activity has been called by sociologists as a "fe-

* This article is the result of the research work funded within the project funded by the National Scientific Centre. The coordinator of the project is J. Brzezińska, Ph.D. (Decision no. DEC 2015/19/B/HS5/03042).

1 See M. Cabalski, Przemoc stosowana przez kobiety. Studium kryminologiczne, Warszawa 2014; D. Woźniakowska-Fajst, Nieletnie. Niebezpieczne, niegrzeczne, niegroźne?, Warszawa 2010, pp. 48-49.

2 P. Piotrowski, "Neurobiologiczne i psychospołeczne uwarunkowania racjonalności zachowań przestępczych — przegląd badań”, Resocjalizacja Polska 2011, no. 2, pp. 197232; B. Hołyst, Problemy młodego pokolenia, Warszawa 1991, p. 149 ff. 
male tsunami" - due to the brutality, aggressiveness ${ }^{3}$ and demoralisation ${ }^{4}$ of the juveniles. This article aims to verify this belief from the statistical point of view based on the data for this category of female delinquents. As to make these considerations comprehensive, the characteristics of the phenomenon of aggression itself were presented.

From a psychological perspective, aggression is a manifestation of behaviour, determined intentionally, which aims at hurting another subject in a determined manner. ${ }^{5}$ Therefore, the given definition includes two elements in its structure: of the subject and of the object. Speaking about the subject, the aggressive behaviour consists in the manifestation of the intention of the controlling subject. The offender concentrates on the aim (i.e., doing harm), strives to achieve it as it is his/her intention. His/her endeavour consists in making the intention, i.e., making another person suffer by doing harm of the determined nature (physical, psychological or mixed), ${ }^{6}$ come true. R. Stach underlines that the result of aggressive behaviour is always the damage or loss of the values important to the victims. ${ }^{7}$ Therefore, the aggression is related to the cre-

${ }^{3}$ See M. Cabalski, Przemoc stosowana przez kobiety. Studium kryminologiczne, Warszawa 2014; J. Błachut, "Niektóre koncepcje kryminologiczne a problem przestępczości kobiet", Archiwum Kryminologii 1989, vol. XVI, pp. 211-244.

${ }^{4}$ D. Krzemionka-Brózda, "Pokolenie transformacji — żeńskie tsunami”, Charaktery, December 2005; Diagnoza społeczna 2005. Warunki i jakość życia Polaków, ed. J. Czapiński, T. Panek, pp. 177-178, http://www.diagnoza.com/pliki/raporty/Diagnoza_raport_2005. pdf, (access: 10.12.2017); J. Różańska-Kowal, Motywacja zachowań prospotecznych i antyspołecznych nieletnich, Kraków 2009; K. Ostrowska, Psychologiczne determinanty przestępczości młodocianych, Warszawa 1981.

${ }^{5}$ A similar definition is formulated by J. Ranchsburg who indicates that aggression is deliberate behaviour (in open or symbolic form), the objective of which is to cause damage, loss or make another person or entity suffer. See J. Ranchsburg, Lęk, gniew, agresja, Warszawa 1989, p. 77; J.M. Stanik, Psychologia sadowa, Warszawa 2013, p. 105; compare also: A.H. Buss, The Psychology of Aggression, New York 1961; J.M. Stanik, "Forms and functions of interpersonal aggression among inmates of a correctional institution”, Polish Psychological Bulletin 1977, no. 8, pp. 231-238.

${ }^{6}$ J. Błachut, A. Gaberle, K. Krajewski, Kryminologia, Gdańsk 2006, pp. 263-264; Z. Majchrzyk, M. Wiszniowska-Majchrzyk, "Beyond norm, beyond pathology - aggression and the art", [in:] Aggression and Violence - Mental Norm and Pathology, ed. K. Daskevicius, Z. Majchrzyk, Vilnius 2001, pp. 117-126.

${ }^{7}$ R. Stach, Zachowanie agresywne, Wrocław-Warszawa 1989, p. 15. 
ation of deficit in their goods. A wider definition is given by A. Frączek who claims that the reflection of aggression are all the activities which aim at doing harm or causing loss of values cherished by the society, inflict pain on somebody or make him suffer morally. ${ }^{8}$ Considering this catalogue of criminal activities committed by juvenile female offenders (e.g., acts of demoralisation, ${ }^{9}$ punishable acts ${ }^{10}$ and offences), various forms of aggression can be identified in their structure. They can take either physical or verbal form or have features of frustration when accompanied by the manifestation of anger, or have an instrumental nature when they aim to eliminate obstacles which make it impossible for the offender to achieve its objective. ${ }^{11}$ Therefore, the aggression is the manifestation of such behaviour, the negative result of which is always reflected (physically and psychologically) in the individual good of the other person or persons, by doing harm to them or causing damage or the intention to cause damage. ${ }^{12}$ As criminologists underline, aggression is a category which is a phenomenon of the clearly negative perception from the point of view of social noxiousness, and especially in terms of sense of threat felt by the victim. ${ }^{13}$ Considering the fact that it characterises mostly male behaviour, it should be stressed that this phenomenon is especially negatively perceived in the context of young women - juvenile offenders. ${ }^{14}$

${ }^{8}$ A. Frączek, Studia nad psychologicznymi mechanizmami czynności agresywnych, Wrocław-Warszawa 1979, p. 13.

9 V. Konarska-Wrzosek, Prawny system postępowania z nieletnimi w Polsce, Warszawa 2013, pp. 58-59; T. Bojarski, [in:] T. Bojarski, E. Skrętowicz, Ustawa o postepowaniu $w$ sprawach nieletnich z komentarzem, Lublin 2002, pp. 51-52; A. Gaberle, "Odpowiedzialność karna nieletnich (remarks on art. 10 par. 2 of the Criminal Code)", [in:] Przestepstwo - kara - polityka kryminalna. Problemy tworzenia i funkcjonowania prawa. Księga Jubileuszowa z okazji 70. Rocznicy urodzin Profesora Tomasza Kaczmarka, ed. J. Giezek, Kraków 2006, pp. 186-187.

10 See Z. Bartkowicz, A. Węgliński, A. Lewicka, Powinności i kompetencje w wychowaniu osób niedostosowanych społecznie, Lublin 2010.

11 J.M. Stanik, Psychologia sądowa, p. 106.

12 J. Błachut, A. Gaberle, K. Krajewski, op. cit., p. 263.

13 Ibidem.

14 From the psychological point of view, the comparison of aggressive behaviour in children of different genders gives divergent results, the instances of aggression start 
The reflexions on the phenomenon of the youngest female offenders justify the question for the factors which determine the activation and manifestation of the aggression considering their gender (women are perceived as of a gentler nature and defensive in their reactions to external factors), ${ }^{15}$ and also their age (young).

The research on the conditions of motives of juvenile delinquents, carried out by J. Gierowski ${ }^{16}$ or Z. Majchrzyk ${ }^{17}$ shows that their catalogue is complex and diverse. The authors bring attention to the fact that the underaged a) act with the intention to harm another person driven by revenge, threat, conflict with the victim, manifestation of strength and domination or the desire to impress their peers, b) act to obtain material goods, e.g., money, satisfy material needs (their own or their closest persons' needs), c) act emotionally: driven by impulse, need of new experiences (new sensations), improvement of mood, release of tension, need of acceptance and sense of security, which they are deprived of, and the sense of impunity for previously committed offences. ${ }^{18}$

to differ at the age of 4, when boys resort to fighting and the girls use verbal aggression (screaming). As a rule, ever since very early childhood, different reactions to instances of aggression in children appear, where the boys are allowed to express their aggression, while open displays of aggression in girls in later stages happen less frequently than in boys (they are allowed to use "medium" manifestations). The fact of punishing aggressive behaviour of girls implies its significant reduction in their behaviour in general; see B. Hołyst, Kryminologia, Warszawa 2016, pp. 344-345; J.C. Wright, J. Kagan, Basic Cognitive Processes in Children, Monographs of the Society for Research in Child Development, Lafayette 1963.

${ }^{15}$ R. Siemieńska, "Środki masowego przekazu jako twórcy obrazu świata”, [in:] Portrety kobiet i mężczyzn, ed. R. Siemieńska, Warszawa 1997, p. 83 ff.

16 J.K. Gierowski, "Diagnoza procesów motywacyjnych - nowe wyzwania i niewykorzystane możliwości psychologii sądowej”, Chowanna 2, 2011, pp. 131-158.

17 J. Majchrzyk, Nieletni, młodociani i dorośli sprawcy zabójstw, Warszawa 2001.

18 The characteristics of behaviour of juvenile offenders show that they frequently take advantage of the occasion to commit an offence, and their acts are taken against weaker victims or vulnerable persons (elderly persons or children); See J. Szymańczak, Przestępczość nieletnich $w$ latach dziewięćdziesiatych $w$ świetle analiz i statystyk policyjnych, Kancelaria Sejmu. Biuro Studiów i Ekspertyz. Wydział Analiz Ekonomicznych i Społecznych. Zespół Spraw Społecznych, czerwiec 1994, http://biurose.sejm.gov. pl/teksty/i-662.htm (access: 20.12.2017); see also K. Biel, Przestępczość dziewczą - rodzaje i uwarunkowania, Kraków 2008. 
However, it is observed that the above categories of motives do not fully match the motives of female delinquents. Some of the presented stimuli are more frequent for juvenile female that male offenders (e.g., improving the mood, acceptance of the environment, need of new experiences), while other less frequent (e.g., threatening, obtaining material funds), and others will not be present at all (the manifestation of strength and domination). These discrepancies may be rooted in the gender individualisation of the analysed groups of offenders. ${ }^{19}$

Currently, young women are gradually breaking socially imprinted stereotypes of perception of their gender as weaker, powerless, and most of all, dependent. Sometimes though, the "breaking" of stereotypes acquires such an advanced character that it leads to the violation of rooted moral rules, and affects the domain of legal norms. ${ }^{20}$ If there are opinions in the interpretation of phenomenon of female delinquency which express astonishment by the phenomenon of the intervention of law enforcement authorities against the actions taken by them, it is even more shocking that young women, or even girls, violate determined standards, the reasons of which are multi-faceted. ${ }^{21}$ Whereas the explanation of the demoralisation process of juvenile female offenders, which consists in the repetition of negative behaviour of a determined nature (e.g., violation of the rules of social coexistence, repeated avoidance of fulfilment of compulsory education or professional education obligation, use of alcohol or other substances in order to induce a state of intoxication, etc.) may be found in the irregularities in the parental control or the influence of wrong peer groups, the curiosity of effect of some substances, the rec-

19 According to the findings of D. Woźniakowska-Faist, the motives of committing prohibited acts by under-aged girls should include the following categories: the desire to obtain a given object, argument, encouragement, endeavour to obtain money, joke, revenge, solidarity with a friend, alcohol, use of a false document; see D. Woźniakowska-Fajst, op. cit., p. 272.

20 See W. Klaus, "Wczesna przestępczość nieletnich i jej skutki”, Archiwum Kryminologii 2005-2006, vol. XXVIII, pp. 203-218; A. Gaberle, Przestępczość i zachowania dewiacyjne dzieci i młodzieży w Krakowie, Kraków 2001.

21 T. Trzciński, "Psychologiczno-społeczne uwarunkowania procesu wykolejania się społecznego i resocjalizacji”, [in:] Problemy psychologii społecznej nieletnich i młodzieży w Polsce, ed. T. Gospodarek, Z Łakomy, Opole 1981, p. 89. 
ognition of schemes which determine the participation of the juvenile in the commitment of determined crimes (e.g., fights, assault, verbal threatening and theft) is more difficult. ${ }^{22}$

According to the findings of G. Konopka, the reasons for the phenomenon of juvenile female delinquency can be found on several levels. ${ }^{23}$ First to mention are the problems to establish and maintain healthy interpersonal relations (lack of communication with peers, as well as parents and custodians), ${ }^{24}$ and serious distortions related to environmental socialisation. ${ }^{25}$ Such girls usually have low self-esteem, are alienated and lonely. Moreover, in the population of young female delinquents, there are individuals seriously conflicted with parents or a parent (usually with the mother) who did not show interest in their development; or the contrary, i.e., girls who were subject to strict parental care and control which precluded them from unrestricted functioning in peer groups. ${ }^{26}$ Therefore, the deficiencies which appear in the educational process of a child are one of the core factors determining the development of wrong behaviour which may result in law infringement. ${ }^{27}$ It should be also stressed that the failure to show affection and interest (especially by the mother) may also determine further irregularities in the emotional development, especially in the case of girls, which contributes to the violation of norms not only of a moral, but legal nature,

22 C. Czapów, "Struktura wykolejenia społecznego młodzieży ze szczególnym uwzględnieniem zachowań autodestrukcyjnych przybierających formę narkomanii”, [in:] Wybrane zagadnienia wychowania zdrowotnego i niedostosowania dzieci i młodzieży, ed. M. Paprocka, Warszawa 1974, p. $10 \mathrm{ff}$.

${ }^{23}$ G. Konopka, The Adolescent Girl in Conflict, New York 1996.

24 Ibidem.

25 See J. Jasiński, Zagadnienia nieprzystosowania społecznego i przestepczości w Polsce, Wrocław-Warszawa-Kraków 1978.

26 T. Trzciński, "Psychologiczno-społeczne uwarunkowania procesu wykolejania się społecznego i resocjalizacji”, [in:] Problemy patologii społecznej nieletnich i młodzieży w Polsce, ed. T. Gospodarek, Z. Łakomy, Opole 1981, pp. 89-90.

27 M. Rode, Psychologiczne $i$ osobowościowe uwarunkowania stylów myślenia przestępczego nieletnich, Katowice 2011; K. Pospiszyl, E. Żabczyńska, Psychologia dziecka niedostosowanego społecznie, Warszawa 1981. 
especially if after running away from home, the funds are desperately needed to make a living (which encourages theft or fraud). ${ }^{28}$

\section{Analysis of the statistical data}

The objective of the analysis of the statistical data presented below on the crime-inducing activity of juvenile female offenders is the verification of the belief of the ascending frequency of such behaviour and the consolidation of diverse instances of aggression in their course. In the statistical summaries presented below, the distinction between three basic groups of behaviour which concern the instances of demoralisation, punishable acts, and determined offence categories (the fulfilment of which is related to the reaction of the legislator or through the relevant regulations of the Act on juvenile delinquency proceedings or on the basis of the Criminal Code) is introduced deliberately as to observe which one is the most prone to progress in quantitative and qualitative terms (increase of aggression). The first of the graphs presented below is the comprehensive summary of the overall number of juvenile female offenders who broke the law in the period 2008-2015.

As the Graph 1 shows, the highest number of girls - juvenile offenders in each analysed age group (aged 15 to 17$)^{29}$ was recorded in the period 2008-2009 (Graph 1). Similarly, it should be stressed that since 2008, a stable yet minor decrease in crime-inducing behaviour has been observed in the analysed group of juveniles. It is worth stressing that the highest percentage of female offenders was recorded in the analysed period 20082015 among 15- and 16-year-old girls (14,659 and 13,843 respectively), then among slightly younger 14- and 13-year-old girls (11,422 and 6,582 accordingly), and the lowest percentage of female offenders presented the group of 17-year-old girls $(5,031)$.

${ }^{28}$ See I. Budrewicz, Środowiskowe uwarunkowania zachowań przestępczych nieletnich dziewcząt, Bydgoszcz 1997; I. Desperak, "Złe dziewczynki, i potworne kobiety — dlaczego media lubią je tak przedstawiać?", [in:] Zachowania dewiacyjne dziewcząt i kobiet, ed. I. Pospiszyl, R. Szczepanik, Łódź 2007, pp. 45-56; E. Gaweł-Luty, M. Sitko, "Świat wartości współczesnej młodzieży w świetle badań”, [in:] Młodzież w sytuacji zmian gospodarczych, edukacyjnych, społecznych i kulturowych, ed. W. Kojs, R. Mrózek, R. Studenski, vol. 1, Cieszyn 1999, p. $151 \mathrm{ff}$.

${ }^{29}$ Both 18- and 19-year-old girls appeared in this overview only incidentally.

Nowa Kodyfikacja Prawa Karnego 47, 2018

(C) for this edition by CNS 


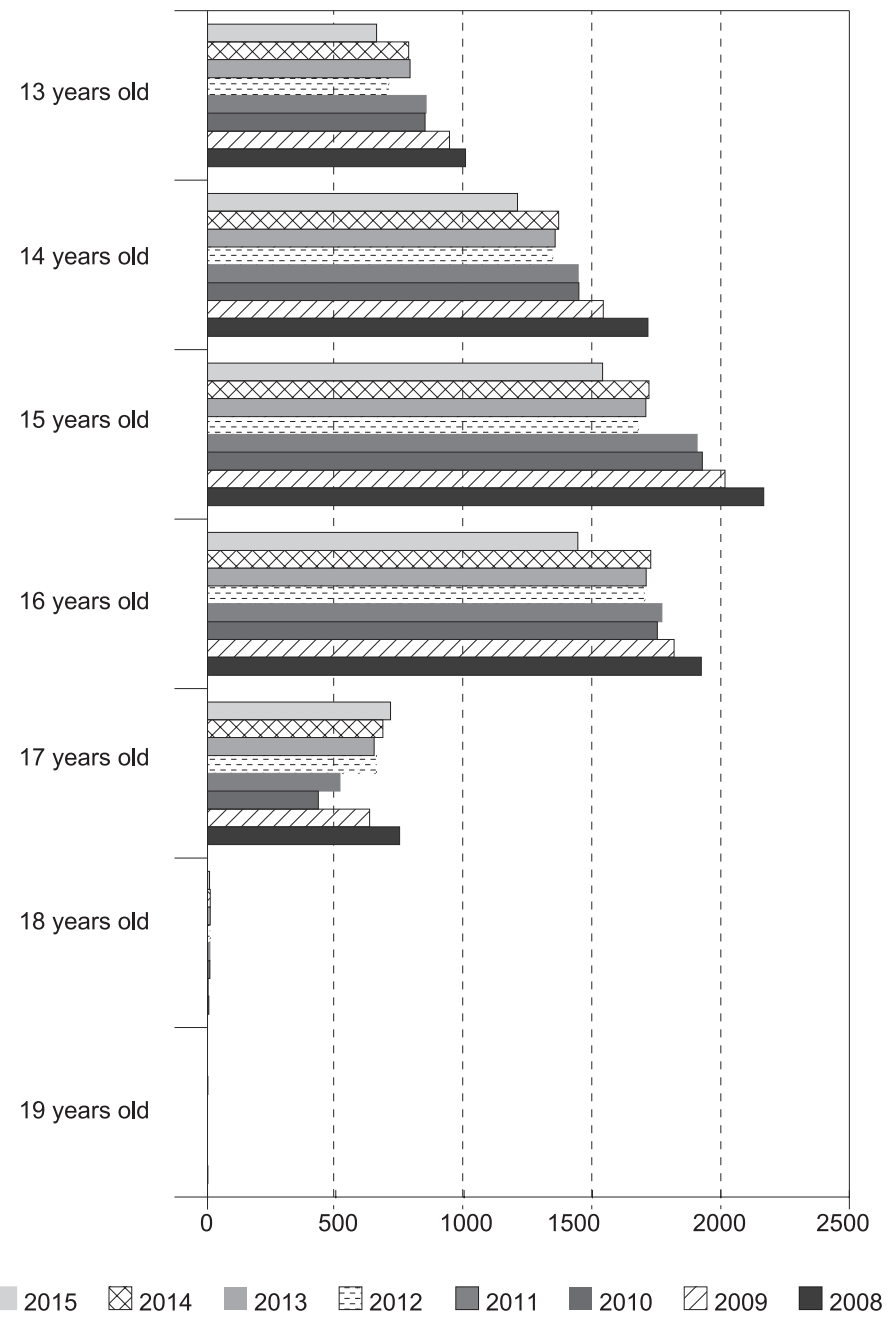

Graph 1. Number of juvenile female offenders

Source: developed based on the data from the Statistical Guidebook of the Ministry of Justice (Polish Informator Statystyczny Wymiaru Sprawiedliwości), https://isws.ms.gov.pl/pl/baza-statystyczna/ opracowania-wieloletnie/ (access: 20.12.2017). 
The 18- and 19-year-old girls appeared in the summary incidentally with 57 and 2 cases, respectively.

A complex catalogue of demoralisation behaviour was provided for in the Act on juvenile delinquency proceedings of $1982 .{ }^{30}$ Therein, diverse instances of the activities referred to as demoralisation acts ${ }^{31}$ are identified, from the infringement of social coexistence rules, through the performance of punishable acts to the repeated avoidance of fulfilment of compulsory education or professional education obligation and the participation in criminal groups. ${ }^{32}$ Considering the distinguished categories of behaviour in the summary below of the demoralisation of juvenile female offenders, a falling trend can be observed which takes its most radical form in the analysed period 2008-2015 in the group of 16-year-old girls (from 1,491 to 1,160) and 15-year-old girls (from 1,343 to 1,106 ), and a similar, yet more moderate, reduction was observed also in other age groups of female offenders. What is important, while observing the acts qualified as demoralisation manifestations among under-aged girls, it should be stressed that in three out of six analysed groups concerning 13-, 14- and 17-year-old girls, a falling trend was recorded twice, for the two first groups of juvenile girls in the period 2008-2012, and later between 2013 and 2015, and in the last group, on the other hand, in the period 2008-2010 and 2011-2015.

At the same time, the observation of juvenile female offenders from the perspective of their living environment allows for the conclusion that acts of demoralisation were committed both in 2008 and in 2015 mainly by female residents of cities. The frequency was several times higher in the

${ }^{30}$ Polish Journal of Laws of 1982 No. 35, item 228, as amended; V. Konarska-Wrzosek, op. cit., p. 59.

${ }^{31}$ V. Konarska-Wrzosek, op. cit., Warszawa 2013, p. 58 ff.; A. Krukowski, [in:] Ustawa o postepowaniu w sprawach nieletnich. Komentarz, ed. A. Krukowski, Warszawa 1984, p. $16 \mathrm{ff}$.

${ }^{32}$ L. Pytka, T. Zacharuk, "Wielowymiarowa geneza zaburzeń przystosowania społecznego", [in:] Pedagogika społeczna. Człowiek w zmieniajacym się świecie, ed. T. Pilch, I. Lepalczyk, Warszawa 1995, p. 397; I. Rzeplińska, "Obraz przestępczości nieletnich w Polsce w badaniach kryminologicznych — przed i po transformacji", Archiwum Kryminologii 2007, vol. XXVIII, pp. 331-343. 
city than in the countryside (the highest was in 2008 in the group of 13- and 14-year-old girls and was five and four and a half times higher in the city than in the countryside, respectively).

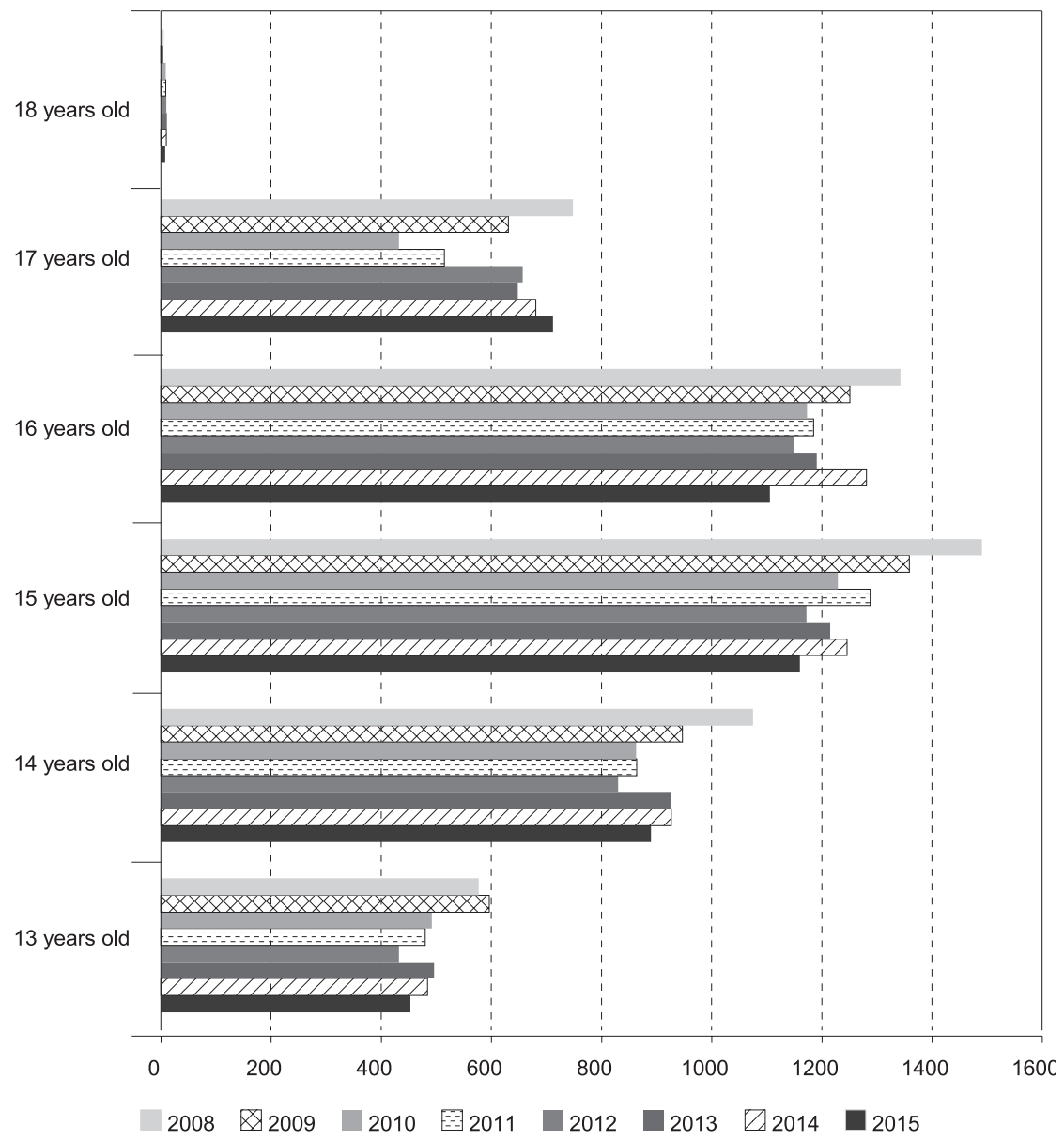

Graph 2. Demoralisation of underaged girls

Source: https://isws.ms.gov.pl/pl/baza-statystyczna/opracowania-wieloletnie/ (access: 20.12.2017).

Moreover, Graph 3 shows another interesting tendency. It can be assumed that in the groups of demoralised juveniles from rural areas aged 15, 16, and 13 , there was barely any change in their number in the analysed period 
2008-2015. Despite the fact that residents of cities still prevail among female juvenile offenders, their number in 2015 compared to 2008 dropped in each of the analysed age groups of girls.

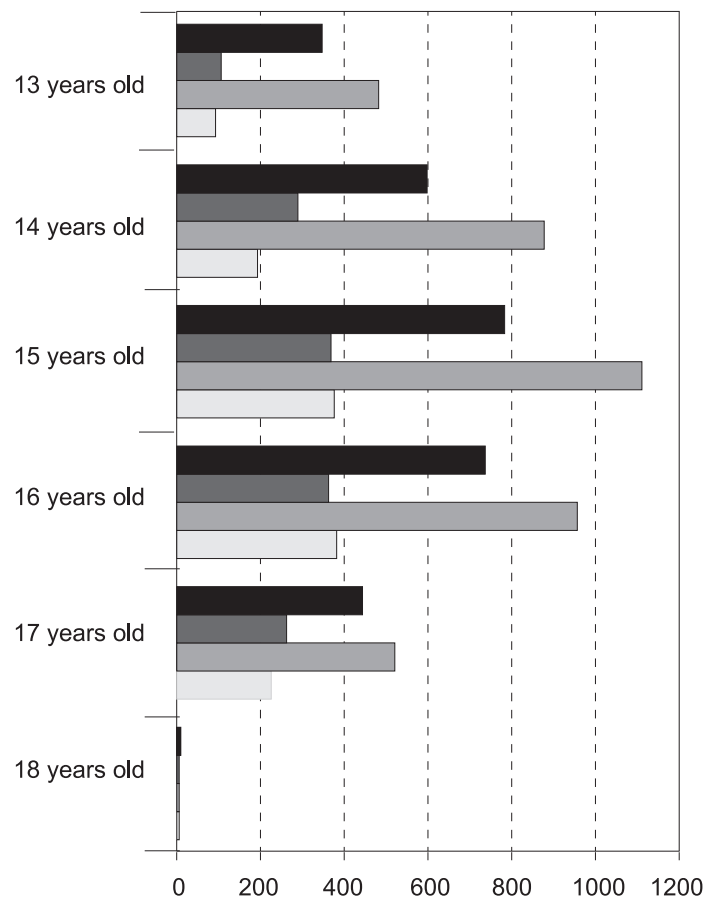

City $2015 \square$ Countryside $2015 \square$ City $2008 \square$ Countryside 2008

Graph 3. Demoralisation of underaged girls

Source: https://isws.ms.gov.pl/pl/baza-statystyczna/opracowania-wieloletnie/ (access: 20.12.2017).

On the other hand, graphs no. 4 and 5 present the summary of another category of crime-inducing activity of female juvenile offenders which are punishable acts committed by them and their distribution area. 


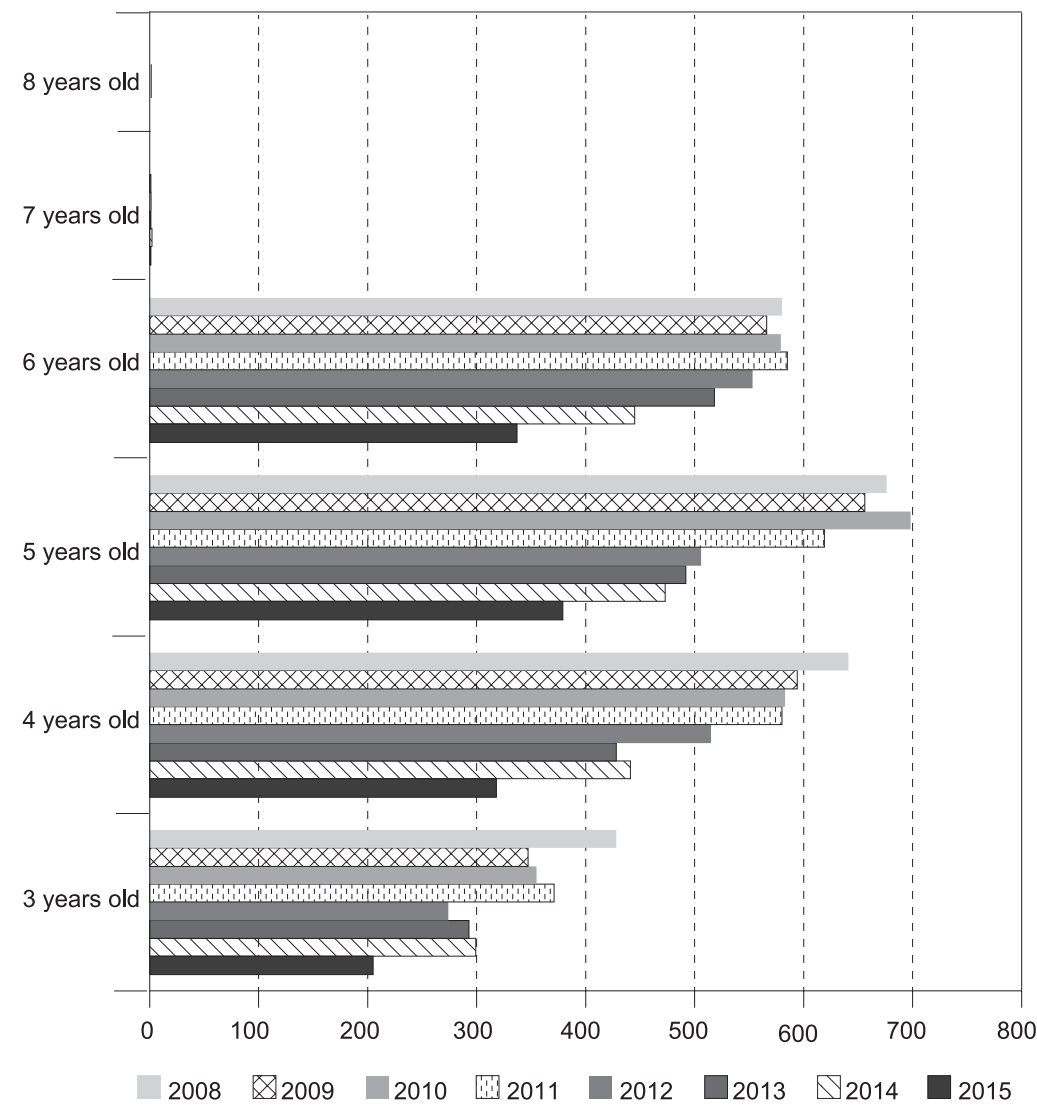

Graph 4. Punishable acts of female juvenile offenders

Source: https://isws.ms.gov.pl/pl/baza-statystyczna/opracowania-wieloletnie/ (access: 22.12.2017)

Graph 4 shows that the number of punishable acts ${ }^{33}$ committed by female juvenile offenders in all analysed age groups ${ }^{34}$ decreased significantly in the analysed period 2008-2015. The drop was most noticeable among 13- and 14-year-old girls, who in 2015 committed only half

33 The category of punishable acts includes offences, tax offences, and misdemeanours listed by the legislator in Art. $1 \S 2$ point 2 of UoPN.

34 In the presented overview, female offenders aged 17 and 18 are virtually not present. 
as many punishable acts than in 2008, whereas in the group of 15 - and 16-year-old girls the drop was only slightly lower and amounted to $45 \%$ and $42 \%$, respectively. The pattern of proportional and regular drop in the participation of female juvenile offenders in the commitment of punishable acts we can observe is distinctive. It ranges from $11 \%$ to $18 \%$ in two- (2008-2010, 2010-2012) or three-year (2012-2015) periods.

Analysis of Graph 5 reveals that punishable acts were, as in the case of girls subject to demoralisation, committed mostly by female juvenile residents of cities (both in 2008 and 2015). However, the frequency of this category of behaviour among female offenders living in urban areas was significantly higher in 2008 . The female residents of cities still prevail in all age groups, yet at present, their frequency in comparison to the earlier analysed period, has dropped by half (the exception is the group of 17-year-old female offenders, for this group the reduction stays at the level of $40 \%$ ). On the other hand, in any analysed age group such a sharp drop in the number of female offenders from rural areas (the highest drop was recorded in the group of 17 -year-old girls and it reached only $19 \%)^{35}$ was observed in the analysed period 2008-2015.

Due to the possibility to broaden the observations of criminological tendencies of female juveniles in the scope of frequency of performance of acts which consist in violation of regulations relevant in terms of criminal law, the presentation of acts indicated in the Act on juvenile delinquency proceedings was supplemented with the analysis of statistical data on the participation of this distinctive category of female offenders in offences, categorised in the criminal code, which are presented in graphs no. 6 and 7.

${ }^{35}$ According to the findings of D. Woźniakowska-Faist, in the period 1999-2006 female juveniles committed 25,172 punishable acts in total, and their frequency was increasing (from 2,310 in 1999 to 3,822 in 2006). The author underlines also that, according to the research she carried out, the prevailing offences committed by female juvenile offenders were mainly thefts, assaults, other violations of bodily integrity, and robberies. On the other hand, according to statistical data from 1997, 1,500 female juveniles were punished for committing punishable acts with didactical and corrective measures and penalties (in the age group of 13 to 16 years old), whereas in 1990 sanctions were applied to 463 girls in the same age group. See D. Woźniakowska-Fajst, op. cit., p. 49 and pp. 262-263; J. Błachut, A. Gaberle, K. Krajewski, op. cit., p. 376; I. Budrewicz, Środowiskowe uwarunkowania zachowań przestępczych nieletnich dziewcząt, Bydgoszcz 1997, p. 168. 


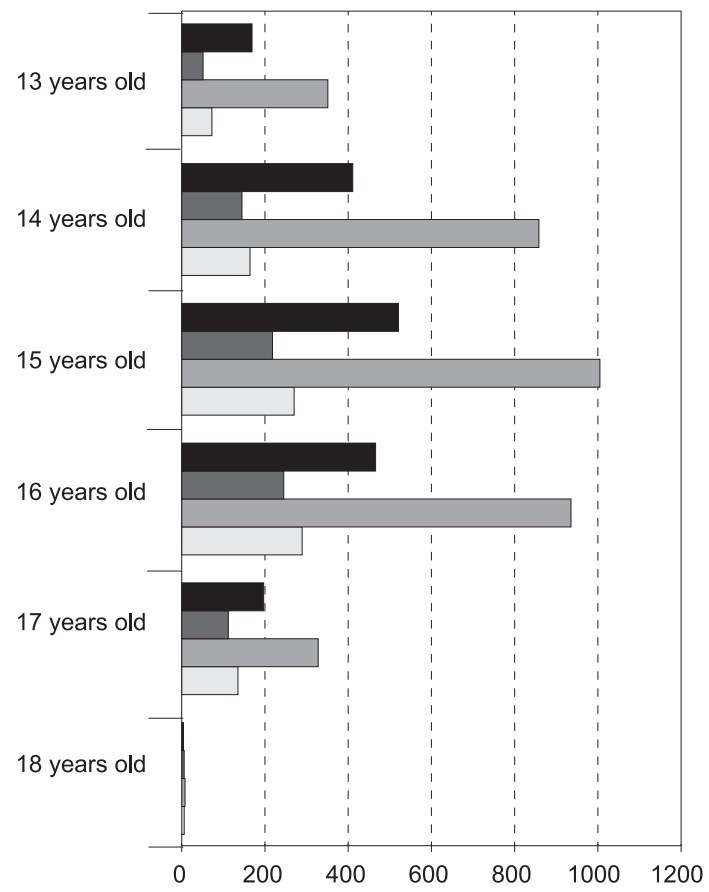

City $2015 \square$ Countryside $2015 \square$ City $2008 \square$ Countryside 2008

Graph 5. Punishable acts of female juvenile offenders

Source: https://isws.ms.gov.pl/pl/baza-statystyczna/opracowania-wieloletnie/ (access: 22.12.2017).

Considering the summaries below, it was concluded that in the period 2005-2013 in the group of female offenders aged under 16 suspected of having committed an offence, three categories prevailed: against property — theft (10,359), against life and health — affray and assault $(8,042)$, against freedom - threat $(7,379)$. This category of female offenders considerably less frequently committed offences listed in the Act on counteracting drug addiction $(3,693)$, theft with assault $(2,998)$ or aggravated theft (burglary - 1,860). 


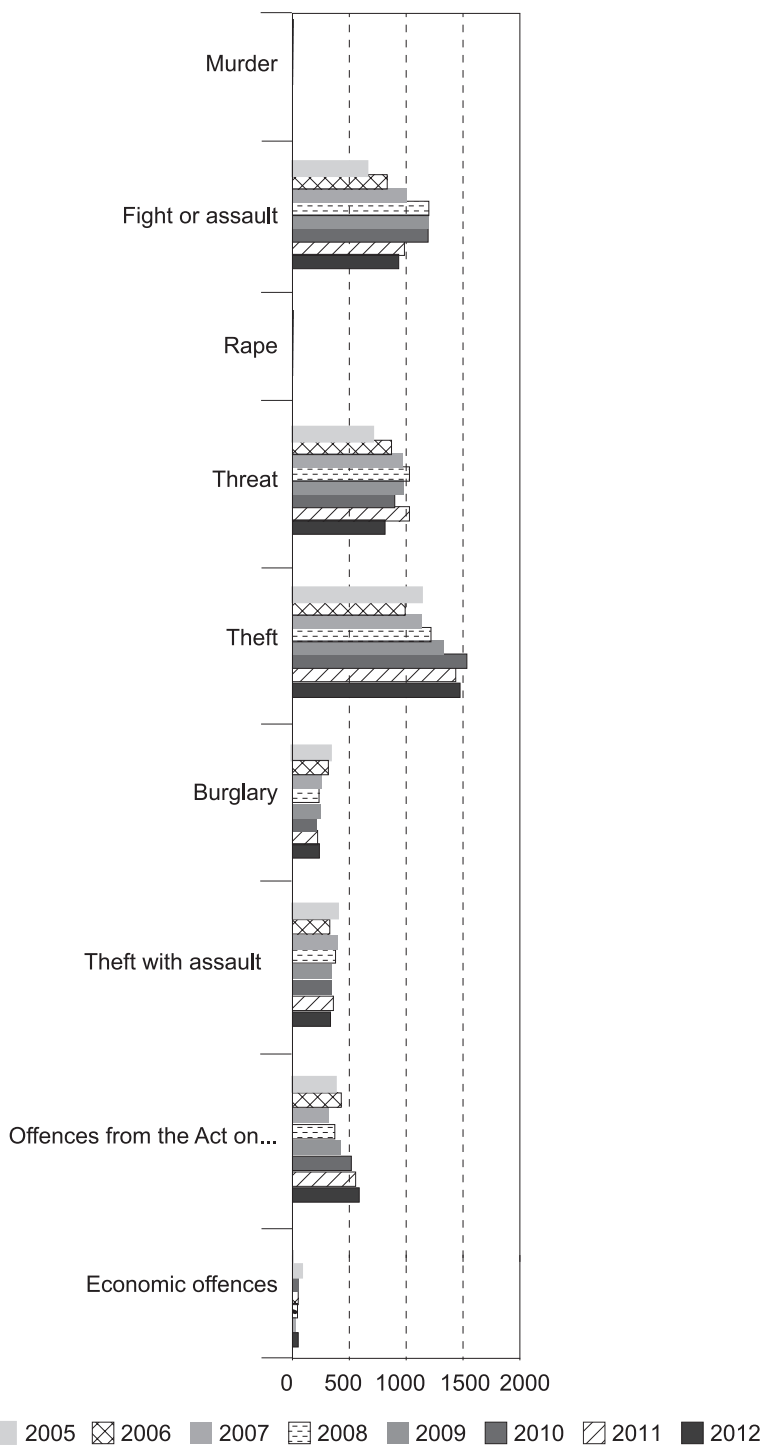

Graph 6. Number of girls aged under 16 suspect of having committed an offence Source: http://statystyka.policja.pl/st/wybrane-statystyki/przestepczosc-kobiet/50869,Przestepczosckobiet.html (access: 28.12.2017).

Nowa Kodyfikacja Prawa Karnego 47, 2018

(C) for this edition by CNS 


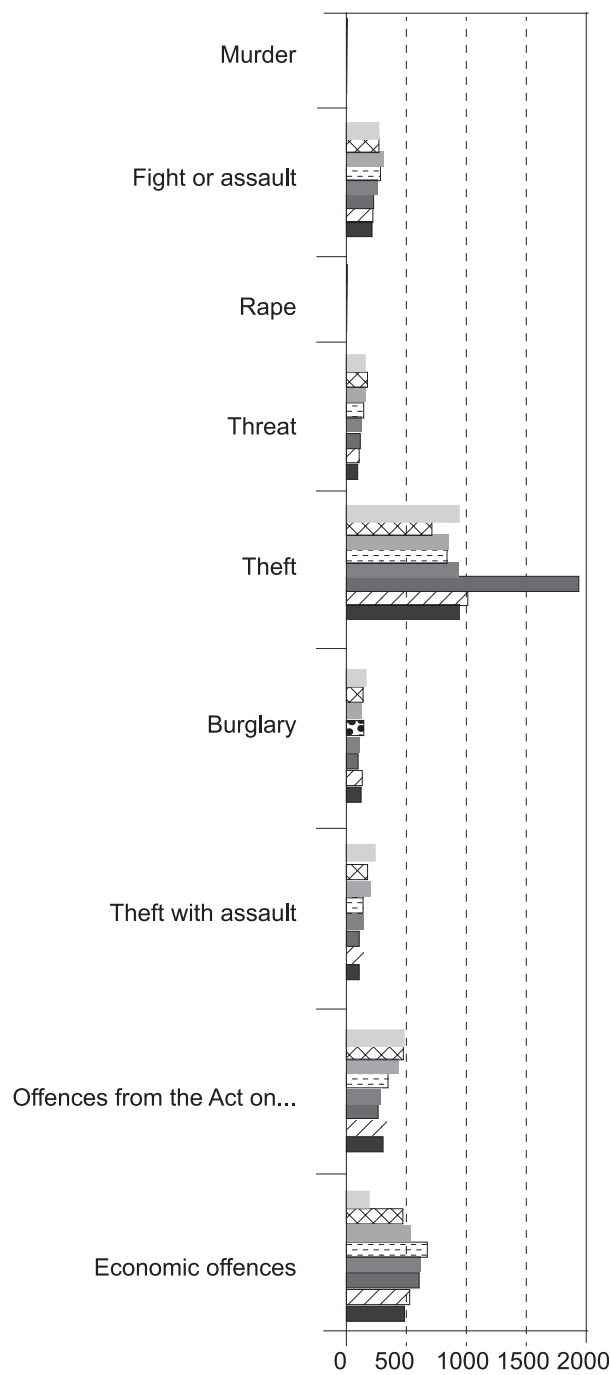

$2005 \otimes 2006 \square 2007 \quad 2008 \square 2009 \square 2010 \triangle 2011 \square 2012$

Graph 7. Number of suspected women aged 17 to 20

Source: http://statystyka.policja.pl/st/wybrane-statystyki/przestepczosckobiet/50869,Przestepczosc-kobiet.html (access: 28.12.2017). 
The characteristics of offences which were supposedly committed by older female offenders aged from 17 to 20 (Graph 7) are slightly different as regards the above-presented conclusions. The only unarguable similarity to the earlier presented category of juveniles is the domination of theft $(8,255)$ in the analysed group, the frequency of which was the highest. It was followed by the following categories of offences committed by older female offenders: economic offences $(4,185)$, offences from the Act on counteracting drug addiction $(2,981)$ and affray and assault $(2,127)$. Less frequent categories of offences committed within this group of offenders include thefts with assault $(1,306)$, burglary $(1,137)$ and threats $(1,152)$. Nevertheless, comparing these two age groups, it should be noted that the representatives of the first one were more "active" in criminological terms in the analysed period (2005-2013) and suspected of more offences, according to the categories analysed in the summary (in the first group - 34,871; in the second - 21,209). ${ }^{36}$

\section{Conclusions}

The reflexions on the characteristics of female juvenile delinquency encourage the formulation of a few basic conclusions. The primary assumption of the article was to verify the thesis about the increase of delinquency levels among the given category of women and finding out whether this group's conflict with law is related mainly to the uncontrolled instances of aggression. For this purpose, the statistical data obtained from two sources: The Statistical Guidebook of the Ministry of Justice and of the Polish Police Headquarters from the period 2008-2015 were presented. The data obtained were structured according to three basic categories of crime-inducing activities of the analysed female offenders: acts being instances of demoralisation, punishable acts, and offences listed in the Criminal Code. It is very interesting that in any analysed age groups of girls (aged 13 to 17$)^{37}$ the growth of any of the illegal acts was observed, on the contrary - their decrease (more or less significant). The belief is supported

36 For comparison, the research of D. Woźniakowska-Fajst revealed that in the period 2001-2006 the number of girls aged under 16 suspected of having committed an offence amounted to 27,869. See D. Woźniakowska-Fajst, op. cit., p. 44.

37 The layout of the research on female juvenile offenders was the result of the availability of the statistical data for the given configuration of the age of the offenders. 
by the following trend: in 2008, instances of demoralisation were reported in 1,075 14-year-old girls, 1,491 15-year-old girls and 1,343 16-year-old girls; whereas, in 2015, they were reported in 890 14-year-old girls, 1,160 15-year-old girls and 1,106 16-year-old girls ${ }^{38}$. On the other hand, the analysis of statistical data on punishable acts consolidates the belief in the decrease in the frequency of crime-inducing activities of under-aged girls. It should be emphasised that in 2008, 428 punishable acts committed by 13-year-old girls were reported and, respectively, over 600 (641, 676, and 580) such acts in each age category of juveniles, whereas in 2015 these data changed presenting a strong downward trend (there were reported, respectively: 205 cases among 13-year-old girls, 318 among 14-year-old girls, 379 among 15-year-old girls, and 337 among 16-year-old girls). It should be also stressed that all categories of illegal behaviour committed by female juvenile offenders were committed mainly in cities (both in 2008 and 2015), yet, both in the case of demoralisation and punishable acts, the decrease in their number was observed in urban areas in the analysed period, in the analysed population of girls.

The downward trend observed above is also reflected in the group of female offenders suspected of committing determined categories of offences from the Criminal Code. Among girls aged under 16, the prevailing illegal acts were the following, according to the findings: theft, affray and assault, threats, followed by offences from the Act on counteracting drug addiction, thefts with assault and burglary. The drop in frequency was observed in all categories except offences from the Act on counteracting drug addiction. A similar yet smaller decrease of delinquency was observed in another age category of female offenders aged 17 to 20 , and the prevailing offence they were suspected of was theft, followed by economic offences and offences from the Act on counteracting drug addiction. Therefore, it should be concluded that the change of age category of the suspected implies a slight change of the profile of acts committed by them. However, it should be added that the decrease in the frequency of offences committed

38 In the remaining age groups, downward tendencies were also observed, however, they were not so spectacular. 
by female juveniles is less spectacular than in the case of punishable acts and instances of demoralisation.

The conclusion is that the total decrease in the percentage of young women - under-aged girls committing illegal acts should be deemed a positive phenomenon. The belief that the youngest female offenders are atypically demoralised was not confirmed in the light of the presented data. At the same time, an extraordinary increase in the aggressive behaviour in the analysed group of girls has not been observed. The analyses show that juvenile girls acted against the law and with the objective of making the victim suffer. An example of this may be the offence of affray and assault, however it was the second most frequent category of offence which girls aged under 16 were suspected of, and from 2010 its level started to decrease. As regards the girls aged from 17 to 20, the number suspected of committing the indicated offence was the fourth category in terms of frequency, and as in the previous group of female offenders, also here a steady fall has been observed since 2010. On the other hand, in case of verbal aggression the reflection of which is a threat, among the youngest female offenders (aged under 16) there has been a decrease observed from 2011, and among older girls (aged from 17 to 20), these threats constituted a marginal offence category listed in sixth place among illegal acts, the committing of which they were suspected.

\section{References}

Bartkowicz Z., Węgliński A., Lewicka A., Powinności i kompetencje w wychowaniu osób niedostosowanych spotecznie, Lublin 2010.

Biel K., Przestępczość dziewczą - rodzaje i uwarunkowania, Kraków 2008.

Błachut J., "Niektóre koncepcje kryminologiczne a problem przestępczości kobiet", Archiwum Kryminologii 1989, vol. 16.

Błachut J., Gaberle A., Krajewski K., Kryminologia, Gdańsk 2006.

Bojarski T., [in:] T. Bojarski, E. Skrętowicz, Ustawa o postępowaniu w sprawach nieletnich, z komentarzem, Lublin 2002.

Budrewicz I., Środowiskowe uwarunkowania zachowań przestępczych nieletnich dziewcząt, Bydgoszcz 1997.

Buss A.H., The Psychology of Aggression, New York 1961.

Cabalski M., Przemoc stosowana przez kobiety. Studium kryminologiczne, Warszawa 2014.

Czapów C., "Struktura wykolejenia społecznego młodzieży ze szczególnym uwzględnie- 
niem zachowań autodestrukcyjnych przybierających formę narkomanii”, [in:] Wybrane zagadnienia wychowania zdrowotnego i niedostosowania dzieci i młodzieży, ed. M. Paprocka, Warszawa 1974.

Desperak I., "Złe dziewczynki, i potworne kobiety — dlaczego media lubią je tak przedstawiać?", [in:] Zachowania dewiacyjne dziewcząt i kobiet, ed. I. Pospiszyl, R. Szczepanik, Łódź 2007.

Diagnoza społeczna 2005. Warunki i jakość życia Polaków, ed. J. Czapiński, T. Panek,

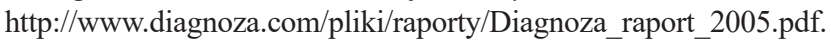

Frączek A., Studia nad psychologicznymi mechanizmami czynności agresywnych, Wrocław-Warszawa 1979.

Gaberle A., "Odpowiedzialność karna nieletnich (remarks on art. 10 par. 2 of the Criminal Code)", [in:] Przestępstwo - kara - polityka kryminalna. Problemy tworzenia i funkcjonowania prawa. Ksiega Jubileuszowa z okazji 70. Rocznicy urodzin Profesora Tomasza Kaczmarka, ed. J. Giezek, Kraków 2006.

Gaberle A., Przestępczość i zachowania dewiacyjne dzieci i młodzieży w Krakowie, Kraków 2001.

Gaweł-Luty E., Sitko M., "Świat wartości współczesnej młodzieży w świetle badań”, [in:] Młodzież w sytuacji zmian gospodarczych, edukacyjnych, społecznych $i$ kulturowych, ed. W. Kojs, R. Mrózek, R. Studenski, vol. 1, Cieszyn 1999.

Gierowski J.K., "Diagnoza procesów motywacyjnych — nowe wyzwania i niewykorzystane możliwości psychologii sądowej”, Chowanna 2, 2011.

Hołyst B., Kryminologia, Warszawa 2016.

Hołyst B., Problemy młodego pokolenia, Warszawa 1991.

Jasiński J., Zagadnienia nieprzystosowania spotecznego i przestępczości w Polsce, Wrocław-Warszawa-Kraków 1978.

Klaus W., "Wczesna przestępczość nieletnich i jej skutki”, Archiwum Kryminologii 20052006, vol. 28.

Konopka G., The Adolescent Girl in Conflict, New York, 1996.

Konarska-Wrzosek V., Prawny system postępowania z nieletnimi w Polsce, Warszawa 2013. Krukowski A., [in:] Ustawa o postępowaniu w sprawach nieletnich. Komentarz, ed. A. Krukowski, Warszawa 1984.

Krzemionka-Brózda D., "Pokolenie transformacji — żeńskie tsunami”, Charaktery, December 2005.

Majchrzyk J., Nieletni, młodociani i dorośli sprawcy zabójstw, Warszawa 2001.

Majchrzyk Z., Wiszniowska-Majchrzyk M., "Beyond norm, beyond pathology — aggression and the art", [in:] Aggression and Violence - Mental Norm and Pathology, ed. K. Daskevicius, Z. Majchrzyk, Vilnius 2001.

Młodzież w sytuacji zmian gospodarczych, edukacyjnych, spotecznych $i$ kulturowych, ed. W. Kojs, R. Mrózek, R. Studenski, vol. 1, Cieszyn 1999.

Ostrowska K., Psychologiczne determinanty przestępczości młodocianych, Warszawa 1981. Piotrowski P., "Neurobiologiczne i psychospołeczne uwarunkowania racjonalności zachowań przestępczych — przegląd badań”, Resocjalizacja Polska 2011, no. 2. 
Pospiszyl K., Żabczyńska E., Psychologia dziecka niedostosowanego spotecznie, Warszawa 1981.

Pytka L., Zacharuk T., "Wielowymiarowa geneza zaburzeń przystosowania społecznego", [in:] Pedagogika spoteczna. Człowiek w zmieniajacym się świecie, ed. T. Pilch, I. Lepalczyk, Warszawa 1995.

Ranchsburg J., Lęk, gniew, agresja, Warszawa 1989.

Rode M., Psychologiczne i osobowościowe uwarunkowania stylów myślenia przestępczego nieletnich, Katowice 2011.

Różańska-Kowal J., Motywacja zachowań prospołecznych $i$ antyspołecznych nieletnich, Kraków 2009.

Rzeplińska I., "Obraz przestępczości nieletnich w Polsce w badaniach kryminologicznych — przed i po transformacji”, Archiwum Kryminologii 2007, vol. 28.

Siemieńska R., "Środki masowego przekazu jako twórcy obrazu świata", [in:] Portrety kobiet i mężczyzn, ed. R. Siemieńska, Warszawa 1997.

Stach R., Zachowanie agresywne, Wrocław-Warszawa 1989.

Stanik J.M., "Forms and functions of interpersonal aggression among inmates of a correctional institution", Polish Psychological Bulletin 1977, no. 8.

Szymańczak J., "Przestępczość nieletnich w latach dziewięćdziesiątych w świetle analiz i statystyk policyjnych", Informacja BSE, no. 662, http://biurose.sejm.gov.pl/tekstyii-662.htm.

Trzciński T., "Psychologiczno-społeczne uwarunkowania procesu wykolejania się społecznego i resocjalizacji”, [in:] Problemy patologii społecznej nieletnich i młodzieży w Polsce, ed. T. Gospodarek, Z. Łakomy, Opole 1981.

Woźniakowska-Fajst, D., Nieletnie. Niebezpieczne, niegrzeczne, niegroźne?, Warszawa 2010.

Wright J.C., Kagan J., Basic Cognitive Processes in Children, Monographs of the Society for Research in Child Development, Lafayette 1963.

\section{Summary}

The purpose hereof was to verify the thesis about the steady growth of crime among under-aged girls and enhancement of aggression accompanying their behaviour in the case of this category of offenders. In the course of the presented research, the first of the views indicated that the above has not been confirmed. It has been noticed that in the period 2008-2015, the frequency of committing criminal offences and other instances of demoralising behaviour by young girls (usually aged 13 to 16 ) fell. Moreover, such a decrease was also reported in the category of female offenders suspected of committing offences from the Criminal Code. What is more, it is difficult to definitively prove that in the analysed population of female offenders, a radical evolution of the aggression manifested by teenagers has taken place. The decrease in frequency of the offences committed by them contradicts this belief. At the same time, the frequency of carrying out acts which 
may be qualified as affray, assault, as well as threats (even with the decrease in their frequency as of 2010) remained relevant for younger under-aged persons (aged under 16) and was at a decidedly lower level among older female offenders (aged from 17 to 20).

Keywords: female delinquency, female offenders. 